\title{
Theoconomy: Rebooting the South African economy
}

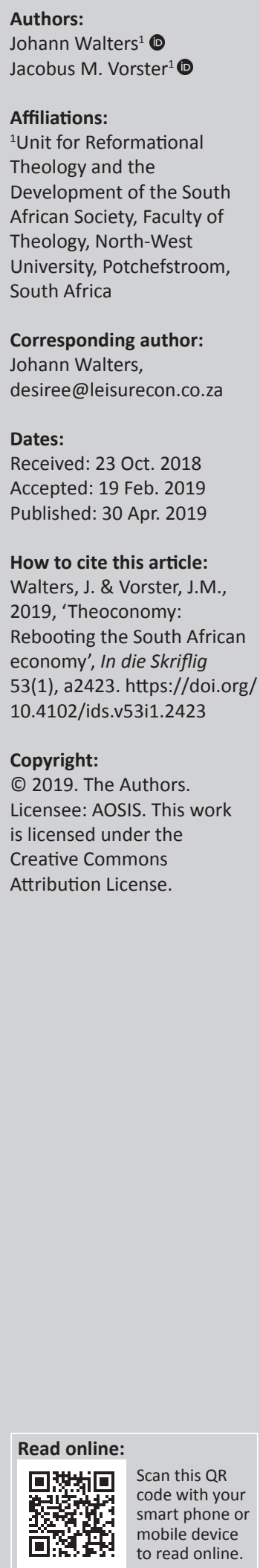

In this article, the reasons why ethics ought to be one of the pillars of an all-inclusive economic growth strategy are expounded. Because of the unethical burden of the South African history, coupled to the myopic way of transforming the post-apartheid society and building an inclusive nation, a deep rooted ethical and trust deficit prevails among the people of South Africa. This is the reason why the South African society is in a sophisticated and self-inflicted war with itself that permeates nearly all segments and components of the politico-economic order. The authors argue that a shared ethics and vision, founded upon a strong shared ethos, would restore and bolster trust and confidence in the economy. This would reform the economic household and place the economy on a growth strategy of $6 \%$ per annum that is needed to improve the economic prospects and allow to break free from the equilibrium of low growth and high inequality in which South Africa has been trapped for decades.

Keywords: National Development Plan; Discernible growth; Inequality; Adam Smith; Parliament of the World's Religions; PUI dilemma; Investment; Job creation.

\section{Introduction: The missing link}

During the 10th BRICS Summit held in Johannesburg, South Africa on 24 July 2018, the South African Department of Trade and Industry (2018) launched an advertising campaign to promote full-scale industrialisation and inclusive growth. The campaign forms an integral part of President Cyril Ramaphosa's drive to improve the South African investment environment and to raise \$100 billion in new investment. In the advertising campaign, 10 reasons why the trade block, among others, should invest in South Africa, were listed as follows:

1. Hot emerging market.

2. Leading diversified economy in Africa.

3. Largest presence of multi - nationals on African continent.

4. Progressive constitution and an independent judiciary.

5. Favourable market access to global markets.

6. Abundant natural resources.

7. Advanced financial services and banking.

8. World-class infrastructure and logistics.

9. Young trainable labour force.

10. Excellent quality of life.

Indeed, a very impressive list of reasons why ordinary South Africans and the world ought to consider investing in South Africa Incorporate. ${ }^{1}$ This initiative of the Department of Trade and Industry to encourage investment and job creation should indeed be welcomed and supported, because sustainable growth is vital for a sustainable society. Especially in South Africa, investment and job creation ought to be bolstered, because the greatest challenge of South Africa Incorporate is indeed job creation and not necessarily inequality as so often considered as the first priority. The World Bank (2018:12), in its 2018 update of the South African economy, is of the view that getting a job is the most promising pathway out of poverty in South Africa. With the official unemployment rate of $26.7 \%$ in the fourth quarter of 2017 and a youth unemployment rate of $53.7 \%$ (South Africa - Economic Forecast 2018), job creation, according to Schüssler (n.d.), remain the greatest challenge of South Africa Incorporate. Creating more and better jobs will reduce inequalities and therefore ought to be on everybody's agenda. However, in the South African society, a contradiction is prevalent in the sense that economic growth is hampered by inequalities - the very same dilemma that the South African economic growth strategies such as that of the Department of Trade and Industry are trying to address. Because of the unethical burden of the past, the PUI (Poverty,

1.The term South African Incorporate denotes the entire South African community including the ordinary citizenry, public institutions, corporate business, religious denominations and civil society organisations. 
Unemployment and Inequalities) dilemma taint the present growth rate and remain therefore an undisputable reality of South Africa Incorporate. South Africa is therefore caught up in a vicious cycle where the 'stubbornly high levels of inequality reflect the weak capacity of many South Africans to contribute to skills-intensive economic development' (The World Bank 2018:48). This is further compounded according to The World Bank (2018:48) by the fact that 'inequalities fuel contestation and policy uncertainty, deterring investments and financial resources needed to innovate and expand productive capacities and to redress historical injustice'.

Notwithstanding this contradiction, the harsh reality is that a growth path of $6.0 \%$ per annum for a period of at least 20 years 'is necessary (if not sufficient) condition', according to Roux (2017:1), in order 'to make meaningful inroads into unemployment, poverty and income inequality'. Roux (2017:1) further observed that 'this target must be achieved in a global economic environment that is less friendly and more volatile than 10 years ago', by implication, more competitive and hostile. This challenge is even more daunting if one considers that South Africa, since the second quarter of 2018, is in a technical recession with a growth rate of below $1.0 \%$ and the annual growth forecast by The World Bank (2018:22) for the period 2018-2020 between 1.4\% and 1.9\% (World Bank 2018:22). This does not bode well for South Africa Incorporate.

Whichever way we look at this, South Africa Incorporate is in need of investment - both from domestic as well as external sources.

Like in all other instances, there is a correlation between investment in monetary terms - whether domestically or foreign - and the general level of confidence and trust. If South Africa Incorporate could bolster sufficient trust and confidence between its own people and with other nations, Schüssler (2017:n.p.) is of the view that the South African economy can indeed grow at $5.0 \%$ that is needed to eliminate or, at worse, reduce poverty, unemployment and inequalities substantially. With business confidence at 39 index points, an unemployment rate of $26.7 \%$ and youth unemployment rate of $53.7 \%$, the challenge is evocative.

Because trust and confidence is earned by being ethical (i.e. thrifty, trustworthy, honest, considerate, incorruptible and having unscrupulous integrity) human behaviour and attitudes are fundamental for economic prosperity. Actually, attitudes determine everything and integrity is an invaluable resource the so-called 'Made capital'. Central to all the effort such as that of the Department of Trade and Industries to undo the ethical burden of the past and place South Africa Incorporate on a growth trajectory, is therefore the worldview, behaviour and, more particularly, the attitude of each citizen towards life in general, towards fellow South Africans and towards the world at large. It is indeed the 'soft factors' of human attitude and behaviour that create an environment to optimise the 'hard factors' as listed by the Department. The 'soft factors', according to Liebig (1994:122), could open channels or, differently said, create favourable conditions that can measurably leverage the financial and other assets of South African Incorporate subject to coherence, encouragement and the freedom and responsibility to do so (Liebig 1994:122). Given the necessary value coherence and encouragement, Liebig (1994:117) argues that it is natural for people not only to accept responsibility, but to actively seek responsibility and participation. It is indeed an innate disposition of humans to take responsibility and develop themselves as long as they feel it is worthwhile and meaningful.

Therefore, no inclusive growth would be possible unless the people of South Africa Incorporate work in unison with a strong coherency and a strong social bond founded on a shared vision and values that are mutually beneficial. This is imperative, because an integrated and shared vision and values are the source of creativity which, in turn, is the source of better solutions, having greater fun and being more proud. Likewise, in difficult times, as South Africa Incorporate is currently experiencing, a strong social bond of solidarity founded upon a strong vision and values that people share, is what make and keep people committed (Robinson 2018). If South Africa succeeds, the nation will regain its legitimacy and remain globally competitive. It is therefore absolutely crucial that the people of South Africa find a way to maintain a very strong social bond and value-based economy. Therefore, because trust and confidence are founded on acceptable attitudes and behaviour, which are mutually beneficial, the 'soft factor' of the human dimension ought to be on top of the agenda for an inclusive economic growth strategy.

What therefore is alarmingly missing in the 10 reasons offered by the Department of Trade and Industry to encourage investment in order to achieve full scale industrialisation and inclusive growth, is the human dimension that define who we are, what we stand for, what we expect from one another, what the rest of the world can expect from us, whether we take responsibility to build an inclusive society, and whether we are trustworthy, thrifty and creative. These are fundamental prerequisites and no inclusive growth will be achieved for as long as these 'soft factors' are weak or superficial and the cause of an ethical and trust deficit among the members of South Africa Incorporate. Likewise, the world will not invest at the required scale if an ethical and trust deficit prevails, and they cannot trust the South African citizenry and not having the confidence in the long-term sustainability of South African Incorporate. To attract sufficient investment, whether domestically or foreign capital, South Africa Incorporate ought to have a solid inclusive platform or enabling environment founded upon mutual trust, confidence and an unscrupulous ethics.

It is therefore of critical importance that an '11th reason' be added to the 10 reasons already listed by the Department of Trade and Industries. The 11th reason could possibly be worded in the following fashion:

We are a society that value our social solidarity as proud South Africans. As South Africans we have a strong ethos, moral and ethical orientation. We treasure and protect human dignity, law and order, and are prudent, honest, trustworthy and incorruptible with the highest degree of integrity, vitality, ingenuity and thriftiness. With us your dignity and estate are secured. 
Such a statement would add an invaluable dimension to the drive for inclusive growth and industrialisation. Wouldn't it encourage domestic and foreign investment? The sad reality is that South African Incorporate cannot profess with any degree of conviction such an ennoble statement. South Africa, as a society, is deeply divided and lack social solidarity. Because the colonial and apartheid past have affected the ethical fabric of society, the remnants thereof is a severe trust and confidence deficit that prevails today. The ethics of the present politico-economic order are to a large degree an upshot of the past and therefore we cannot deny the role of the apartheid legacy. However, the myopic manner of going about transforming South Africa Incorporate and building a new inclusive nation, have tainted the revolutionary hopes of a 'rainbow nation'. Not only are the dignity and estate of ordinary citizens spoiled and threatened by apartheid style machination of power, the bond of solidarity between all peoples are superficial and weak. This then is the missing link in creating an inclusive economic household that can effectively undo the unethical burden of the past and place South Africa on a growth trajectory that is founded upon deep rooted ethics and consequential confidence and trust. In South Africa Incorporate the missing link is therefore regrettably the weak or at least superficial social bond that is founded on a very questionable moral and ethical fabric of society with a consequential severe lack of mutual trust and confidence.

\section{Deep-rooted ethical and trust deficit}

The reality is that South Africa Incorporate experiences a deep-rooted ethical and trust deficit. South Africa Incorporate is, according to Abedian, Mosala and Sehume (2018:265), in a 'sophisticated and self-inflicted war with itself that permeate nearly all segments and components of the social system'. As already eluded to, the deeply rooted ethical and trust deficit has a long history founded upon colonialism, apartheid, the apparent 'unearned white privileges' and the 'inequalities along racial lines' (Du Preez 2018:1).

To compound the ethical and trust deficit that emanated from the unethical burden of the past, the ethical and trust deficit has been further entrenched by maladministration and corruption with the total amount exceeding the R1 trillion mark which was stolen or completely wasted over the last decade (Du Preez 2018:2). Since 2009, South Africa Incorporate is caught up in a systemic spread of corruption in particular in the public sector; the private corporate sector is not excluded. (Abedian et al. 2018:269). This systematic corruption and the capturing of part of the state and some privileged persons, have resulted in a material loss of accountability in governance. Consequently, Abedian et al. (2018:269) argues that the 'revolutionary hopes have been turned to cynical and widespread disappointment, anger and daily frustration'. Coupled with this systematic corruption, the business sector and the rich - black and white - remain largely confined to the pursuit of narrow and short term materialistic gains (Abedian et al. 2018:265). This short term materialistic approach and vulgar materialistic culture, according to Terreblanche (2012:2), is today deeply rooted and entrenched in the post-apartheid politico-economic system as a neo-colonial satellite of the American - led neoliberal global empire - with the result that South Africa Incorporate, due to the deep rooted sense of self-enrichment and the wide spread absence of value consistency, is caught up in a vicious circle. This is a vicious circle characterised by racial exclusion, racial prejudices, apartheid style machination of power, colossal abuse of fiscal power and resources, conspicuous consumption and a very superficial regard by both black and white elite for the daily struggles of the poor that remain disenfranchised from the economy. The result is that the efforts to ameliorate the inequality and poverty have been severely diminished and therefore the PUI dilemma and the ethical deficit are even worse today.

The ethical and trust deficit is evident from recent research done by the consulting group, Brunswick. According to Brunswick (De Lange 2017), 76\% of the South African citizens have no confidence that the country is in good health and $64 \%$ are of the view that corporate executives have no concept or empathy with the life challenges of the ordinary people. Only $31 \%$ of the respondents agree that business leaders are honest and trustworthy. Furthermore, the respondents reckon that business leaders are only concerned about their own self-interest. What is further illustrative of the ethical and trust deficit is that only $37 \%$ of ordinary people reckon that government is effective, whilst only $37 \%$ of the respondents reckon that capitalism is a positive force.

In its review of the South African economy, The World Bank (2018:vii) warns that a further degradation in the moral and ethical fibre of South Africa Incorporate is not excluded. They argue that if South Africa wants to significantly improve its economic prospects, it will require breaking away from the equilibrium of low growth and high inequality in which the country has been trapped for decades. The World Bank (2018:vii) argues that, in this equilibrium, 'slow growth and high inequality reinforce each other: inequality fuels the contestation of resources which discourages the investment needed to accelerate job creation and reduce inequality'. The World Bank (2018:32) further observed that 'it is likely that severe inequalities in South Africa [will] affect economic growth, leading to contested resources, fuelling fragility'. A further degradation of the moral fibre would therefore be the cause that the ethical and trust deficit will be intensified and entrenched with severe consequences for the levels of poverty, unemployment and inequalities which, in turn, would undermine the stability and sustainability of South African Incorporate.

\section{Ultimately the gap between rich and poor will become explosive}

It is therefore imperative that the ethical deficit and moral orientation should be addressed as part of any economic stimulus package such as the laudable initiative of the Department of Trade and Industries to create inclusive growth. 
Unless South Africa Incorporate establish a strong ethos based on a shared vision and shared values, the level of trust and confidence among the people of South Africa and also the larger global societies' trust and confidence in South Africa Incorporate will falter.

Why should we care about the ethical and trust deficit and work diligently in restoring the levels of trust and confidence? Essentially the answer is that, unless these fundamentals are addressed, South Africa Incorporate will not grow at the 6\% per annum that is required to undo the unethical burden of the past. The contestation of resources will intensify, fuelling unethical conduct and wastage of public resources by politicians and public servants. Likewise, the executive and management of large state-owned and private companies alike would continue working to get the most for themselves, rather than to improve society. In doing so, the ethics of service will further deteriorate. Equally important, the vulgar materialistic culture of the Neo-Liberal economic system that persist in the post-apartheid South Africa will not be addressed. The conspicuous consumption culture that is inhibiting the rapid accumulation of savings and direct investment in the economy by the rich households, which are so desperately needed, will continue to have a negative effect on growth. This would lead to an inflationary economy and widespread unemployment with most of the population living in poverty, unable to sustain a dignified standard of living.

A shared ethos and vision, founded on a strong shared ethics, ought therefore to be our highest priority. With that is also implied that the policies, the process of policy making and implementation of policies ought to be consistent with the shares vision, ethos and values. If we do not take this aspect seriously and handle it with greater care and urgency, South Africa Incorporate will remain trapped in a cycle of high inequalities and slow job creation. Furthermore, the sophisticated and self-inflicted war will persist and South Africa Incorporate will slide further back into obscurity with, inter alia, the following consequences (Packirisamy 2018):

- State institutions will further falter.

- Corruption will undermine South Africa democracy.

- Political accountability will be further destroyed.

- State capture by powerful elite will become even deeper entrenched.

- The Neo Liberal economic system will undermine the South African democracy.

- The level of productivity will remain low and undermine international competiveness.

- Racial exclusion will intensify and cause irreparable harm to the level of mutual trust and confidence among the peoples of South Africa and between nations.

- Private enterprise will deteriorate and fail to meet their social obligations.

- Investment confidence will be destroyed and the South African economy will remain depressed and face further downgrading of its credit worthiness.

- Ultimately, South African's liberal democracy will collapse.
The world and the people of South Africa would then come to an unambiguous conclusion that in South Africa Incorporate, their dignity and estate are not secured. Like in all other instances, the lack of trust and confidence as a result of a deep-seated ethical deficit would lead to a sudden collapse. Need we remind ourselves of the collapse of big corporations like Enron and Steinhoff or the collapse of the Roman and Ottoman Empires?

We do not have to be fixated only on the current economic woes, turbulence and moral deficit. South Africa Incorporate could regain its solution, but need to visualise the long term picture of a shared inclusive economy where the potential of all its people and all the resources of the land could bring true and lasting prosperity. To achieve that, South Africa Incorporate should build a strong social bond based on the ethics of solidarity where each person's dignity and estate are treasured and protected. Only then will the laudable initiative to promote industrialisation and inclusive growth be successful. Until then, all the good attributes, qualities and features of South Africa Incorporate, as so well-articulated in the advertising campaign of the South African Department of Trade and Industry, would lack potency and energy to restore the dignity and legitimacy of South African Incorporate in order to optimise its full potential. The economy of South Africa therefore ought to be rebooted, restarted and revived and given a fresh impetus. What is required is a holistic transformation. This holistic transformation starts with a strong social bond founded upon a collective ethos and ethics upon which mutual trust and confidence can be build.

\section{Ethics and growth}

It is indeed an undisputable fact that major strides in nation building since the dawn of the new nation in 1994 have been made in South Africa. The people of South Africa have established the necessary social processes and have upheld a fair degree of economic prudence in tackling sensitive socioeconomic challenges such as poverty, unemployment, distribution and equal opportunities (Vorster 2007:262). However, 24 years into democracy, the 'Rainbow Nation' and the revolutionary hopes are dissipating. Coupled with that, the ethics of the nation and levels of trust and confidence have reached a very low ebb and are retreating. The result is that the spread of ethical failures across the South African Society have reached pandemic levels. Presently, South Africa Incorporate lacks substance when it comes to citizenry or having a strong social bond founded on mutual trust and confidence. According to Patrick Kuwana (cited in Van Zyl 2017), at the heart of state capture and the struggling economy is a fundamental trust deficit and lack of ethics. Kuwana also asserts that the real challenge South Africa is facing today is the collapse of the foundational pillars of an ethic that is a prerequisite to creating a conducive environment that encourages people to trade and do business with each other (Van Zyl 2017). Kuwana then raised the very pertinent question whether we (South African Society) have become a society so driven by greed and selfish 
material accumulation that we have tossed out the values of moral humanness which are a major ingredient for achieving collective prosperity. One of the major problems in South Africa, especially during the last decade or so, is the focus on greed and corruption to make as much money as one possibly can. It has become very destructive. Today the people of South Africa Incorporate is living as if we have a democratic country. But what has transpired is in fact individualism and solipsism: living with the freedom to do whatever we want, but not being responsible for anything else (Liebig 1994:189). This reminds of what has transpired after the French Revolution, as a society has evolved in which individuals and groups constantly appeal to rights against others without recognising any responsibilities of their own (Küng 1998:99). In this way, the spirit of an ethic of responsibility was undermined.

By undermining the ethics of responsibility, the people who are suffering the most is the poor $(50 \%$ of the nation's population) that remain disenfranchised from the economy. Consequently, South Africa Incorporate is the most unequal nation in the world with the rich living in comfort and the disenfranchised poor in squalor, poverty and neglect. South Africa Incorporate ought therefore to revisit how we live, how we go about doing business and the progress we have made in improving the general conditions made to live dignified and equal lives. In attainment thereof, we need a new paradigm for the economic household which, as Küng (1998:59) argues, 'combines a sober perception of interest with a basic ethical orientation'. Related to the aforesaid, South Africa Incorporate has to work with the necessary urgency in building a much stronger social bond between all people of South Africa, white and black, in order to create conditions conducive to the well-being of all to build a nation with a collective morale where everyone is committed to a shared mutually inclusive vision and shared values that underpin our mutual hope to live dignified and equal lives. Having said that, the time has also come that South Africa Incorporate must be prepared to alienate those who do not accept this as a fundamental reality. If South Africa Incorporate does not get it right, the nation will lose its legitimacy and underperform and underutilise its full potential. With the result that the world is going to pass us by if we keep going down this road.

The authors therefore agree with Devi Rajab (2016) that South Africa Incorporate is indeed at a tipping point as a successful nation. Deep seated reform is now needed. As the economy is at the crossroads of human aspirations and human endeavours, the way we conduct ourselves in the economy, in particular our attitudes to racial exclusion, the PUI dilemma, self-enrichment, conspicuous consumerism, corruption and economic prejudices require urgent attention. Coupled with that, the people of South Africa have to realise that the time has come to accept in our hearts and minds that with freedom comes economic responsibilities. As De KlerkLuttig (2018) argues: every person has to accept that he or she has a duty to the larger body.
To achieve this in the economic household would undoubtedly require a radical transformation of our attitudes and behaviour. Because ethics is the province of right attitudes and acceptable behaviour, it needs to be invited back into the moral psyche of South Africa Incorporate. Unless all people change positions and become smarter, which implies that they will have a better attitude towards one another and in general living life in a way that bolster trust and confidence, South Africa Incorporate may experience further downgrading that would derail economic growth and the eradication of poverty, unemployment and inequalities. This may be the last chance to relive ethics and economic growth, argues Abedian (cited in Stadler \& Prince 2016). The current economic meltdown and the avalanche of evidence of an amoral economic household infested with individual selfishness and associated corruption, should therefore urgently bring us back to shine the spotlight on the ethics underlying the South African economic household.

Having said that, it is not implied that the people of South Africa have no inherent ethical consideration. This is indeed not the case. What is indeed ubiquitous is the gap between what we profess by conviction and how we live. As Abedian et al. (2018:273) put it, 'the gap between formal and informal ethics is pervasive'. According to Abedian's observation, global best practices are exposed by politician and executives. Yet, operationally, in their organisational and managerial conduct, there is little evidence of the values, standards and practices that they formally expose.

The superficial ethics and, in many instances, the lack thereof, are therefore the problem that South Africa Incorporate ought to resolve in order to restore the levels of trust and confidence, and to bring the economy back on track. As an economy function like a household, ethics affect how people function as members of the household. Ethics affect how people make decisions and lead their lives. Ethics do provide good tools for thinking about moral issues and offer a framework to come to explicit and implicit value judgements. As ethics is concerned with other people's interest, with the interest of society, with God's interest, with the ultimate good and purpose, et cetera, ethics develop and energise the human spirit to become considerate towards others with a greater awareness of the consequence of one's actions (bbc.co.uk 2018). All in all, ethics direct the human spirit to live fulfilling lives through serving a higher purpose. The phrase serving a higher purpose means 'to connate those thoughts and actions which enhance the affective, intuitive and spiritual aspects of the human experience' (Liebig 1994:191). Essentially, 'consciously or unconsciously grasped' wrote Liebig (1994:191), 'these elements of every human life ultimately determine whether we know who we are, what we are here for, and whether we have any sense of having fulfilled our destiny'.

Hence, they are 'higher' in that they transcend and exceeds the visual, the material and the rational (Liebig 1994:191). In this sense, ethics and social responsibility cannot be used interchangeably, 'If you're trying to be ethical or responsible' 
wrote Liebig (1994:153). 'you need to be aware of the impact you're having on people and the world and try to make that impact positive.' Being ethical is therefore more than the narrow pretext of 'social responsibility' as so often implied in business ethics. In its broadest sense, being ethical in the economic household implies that the ethical person subscribes to the Golden Rule of Humanity as a categorical imperative. The Golden Rule of Humanity as a narrative is worded differently by religions, but essentially implies the following: willing for all people what we deserve to be done to ourselves. In other words, what you do not want for yourself, do not do it to another person. Likewise, whatever you want people to do to you, do the same to them and what you wish for yourself, you wish for others. Work diligently to help others to achieve the same. Adam Smith (1759:229), the father of modern economics, put it this way: 'to promote, instead of obstructing the excellence of your neighbours'.

This ought to be done, according to Smith (1759:229), not because 'we love it for its own sake, but rather do it independently of any such consideration'. In other words, not because of the love for oneself or the love for humanity, but because it is the right thing to do. Central to this Golden Rule, is human solidarity; a strong social bond and fellow feeling for the well-being of others. Upon this Golden Rule, a society such as South Africa Incorporate would be able to build a strong economic household that is founded on mutual trust, respect and confidence. This is the golden path to economic prosperity. Therefore, to achieve the radical transformation of character and to find a strong ethos that bolster cooperativeness and energise the South African spirit, ethics need to be invited back in. Intellectually, South Africa Incorporate need to begin a genuine search for a realistic and sustainable alterative ethical paradigm that could provide new energy and focus. If we wish to reboot, restart or revive the economy, we need to agree on an ethos that build upon a shared vision and shared values that could create an inclusive-humane economy.

\section{Shared vision and values}

To regain our moral compass and to reboot the South African economy, we need a systemic solution. South Africa Incorporate need to operationalise and institutionalised a new platform that include an intentional process of moral regeneration, rebuilding relationships, changed attitudes and behaviour, and foster a higher level of consciousness and mindfulness.

It is therefore imperative that South Africa Incorporate, as Ka'Nkosi (2016) asserts, retrace its steps as a centre of progressive thinking that was most evident during CODESA and the birth of the new nation in 1994 in order to find a shared vision and formulates shared values that could guide and shape the economic household in particular. In this regard, notice ought to be taken of the views of Enoch Godongwana (2018), Chairperson of the African National Congress's subcommittee on economic transformation:

that the current economic meltdown is a call to action for all South Africans to work together in order to find a shared vision for economic growth and job creation. (n.p.)
South African Incorporate ought to build a culture of shared values that give expression to a shared vision. South Africa Incorporate ought to develop in informal terms a culture where every person feels cherished and cared for not only materially, but, of most importance, also emotionally and spiritually. In more formal terms, a culture of shared values may include the commitment to economic growth, fairness, responsibility, respect and fundamental rights. Such values, whether informal or formal, means a shift in society psyche that are previewed in words such as rebalancing, rethinking, community, diversity, purpose, responsibility, evaluation, dematerialized, dialogue, transcultural, integrity, spirituality and consciousness. Such words stand in considerable contrast to those that characterising our present ethos of individualism, solipsism, consumerism and materialism (Liebig 1994:224).

Essentially the core of such shared ethic is founded on two basic principles: first, every human being must be treated humanely; and second, what you wish done to yourself, do to others (Küng 1998:110)

\section{A culture where every person feels welcomed}

There should indeed be a culture of shared values that are humane. As Jay Naidoo (2017:n.p.) so aptly put it: 'the time has come that South Africans should care more for one another'. It is only then that every person would show loyalty and dedication to the shared destiny of South Africa Incorporate. Once this culture is entrenched in the moral, economic and political fabric of society, each person will protect and work towards the well-being of South Africa Incorporate and the economy will prosper again. With that, the culture of self-enrichment, corruption, vandalism and lawlessness will subside, and a much stronger ethos and resolve will prevail among the majority of people - rich and poor, black and white. Then every person will take responsibility for the mutual well-being of society and a renewed energy will emerge. According to Liebig (1994:43) 'people who share a common direction and sense of community can get where they are going more quickly and easily because they are traveling on the thrust of one another'.

The question that ought to be raised is whether such a shared vision and shared values are indeed attainable in South Africa Incorporate. Can South Africa Incorporate become a truly 'people-centred society' as envisaged by President Mandela in May 1994 or the 'rainbow nation' as envisaged by Archbishop Tutu, or is this only fairy-tale optimism that is superficial and naïve. With regard to the economic household, a similar styled question ought to be raised: Will South Africa Incorporate remain caught up in a vicious cycle of selfenrichment, corruption, abuse of public resources, a superficial social bond and a near neglect of ethics, morality and spirituality? Or will South Africa Incorporate experience in the next 24 years a virtuous cycle of expanding equal opportunities, fair treatment of all, building capacities and abilities in order to be dutiful, and reduce poverty, unemployment and inequalities? In search of an appropriate answer to the question, we have to start with the National Development Plan. 


\section{The national development plan}

South Africa Incorporate should take its que from the National Development Plan as formulated by the National Planning Commission (2011). The National Planning Commission is putting its trust in a 'new story' that creates 'a virtuous cycle of expanding opportunities'. The National Planning Commission, as cited in Terreblanche (2012), formulates the main challenge ahead for South Africa Incorporate as follows:

... to attack the plight of poverty and exclusion and [promote] economic growth at the same time, creating a virtuous cycle of expanding opportunities, building capacities, reducing poverty, involving communities in their own development, all leading to rising living standards. (p. 116)

This great endeavour relies on the success with which South Africa Incorporate can entrench 'a new story' that gives rise to a virtuous cycle that requires sacrifices of all sectors and interest. This 'new story' will remain ineffective unless, as the National Planning Commission (cited in Terreblanche 2012) is putting it:

every citizen is concerned about the wellbeing of all other citizens, and the development of South Africa means the development of each and every one of us who lives here. We must build on our social solidarity, which, through history and heritage, has demonstrated our aspirations to create a caring South African Society. (p. 117, [author's emphasis])

The 'new story' is therefore founded on the Golden Rule of Humanity as mentioned before. This implies a Social Solidarity or Social Bond that Adam Smith, like the Stoic philosophers, articulate so well. According to Smith (1759) each person ought to regard him- or herself:

as a citizen of the world, a member of the vast common wealth of nature ... We should view ourselves ... in the light in which any other citizen of the world would view us. What befalls ourselves we should regard as what befalls our neighbour or, what comes to the same thing, as our neighbour regards what befalls us. (p. 141)

How should this be interpreted in a South African context with its deeply entrenched racial divide and prejudices? It implies that the social solidarity ought to be founded upon a shared ethos and shared values that recognise our 'Africanacity', our individual desire for self-betterment and authenticity, the right to live a dignified and fulfilling life, and to work towards the amelioration of inequalities and poverty through discernible growth that are socially just, peace fostering and earth friendly. Having said that, the question is how we should go about articulating and entrenching the 'new story'. Not much is being said or done about the 'new story' that is so well articulated in the National Development Plan. In fact, we do not hear much today about the National Development Plan.

The 'new story' ought to be created step by step and much can be done by people of reason and sensibility to operationalise and institutionalise the 'new story'. As the 'new story' is founded on social solidarity, which, in turn, is rooted in a shared vision and values, the question is how South African Incorporate ought to go about formulating this shared vision and values. Social solidarity or, more particularly, the ethical principle that every citizen ought to be concerned about the well-being of all other citizens and the development of each and every one who lives here, have many dimensions within the economic household where human aspirations and endeavours coincide on a daily basis - at times more integrated and at times very haphazardly. In this regard, to give effect to the principle of social solidarity, many rules of an ethical nature ought to be formulated that can be shared by a growing heterogenetic society with different values, worldviews and spirituality.

In the remainder of this article two possible solutions will be further expounded. Firstly, the role of peoples of faith or religious groups will be articulated; and secondly, the article will briefly refer to the outcome of a most recent doctoral research project under the auspices of the Unit for Reformational Theology and the Development of the South African Society at the North-West University, South Africa (see Walters 2018).

\section{People of faith}

People of faith, as organised in different religious denominations, have an important role to play in formulating in concrete terms the broad framework of a shared ethos and shared ethics for South Africa Incorporate in general and then, more particularly, the economic household or the arena or point of convergence of human aspirations and endeavours. Although the world's religions have doctrines, they all advocate a common ethic of basic standard, principles and rules that could delineate the direction, method, purpose and attitude of the South African economic household. After all, the ideas that great religions and therefore people of faith stand for, have always been at the centre of things. Likewise, they have to be at the centre of whatever we in South Africa are going to make out of this turbulent times. The authors of this article therefore believe that the core values, which cut across all religions and which are deeply founded in the Golden Rule of Humanity, could be the starting point. The shared ethics and ethical principles and virtues that could to be entrenched in the moral fibre of South Africa Incorporate ought not to be arbitrary values for political convenience, but should rather be deeply rooted in the shared principles and rules of the various religions and spiritual traditions. For this reason, the ethical principles, rules and virtues will be very intimately related to the greater purpose and goodness of life than political expediency founded on transitory and consequential values and principles.

This very ennobling idea is very much reliant upon whether religions or people of faith could set aside doctrinal difference and work towards an a-dogmatic, pure and rational set of principles, rules and virtues that could be shared by all reasonable and sensible persons. It is also considerably 
dependent on whether religions could focus on finding a shared obligation of conscience which is not aimed on what is good or right in the abstract, but on what is good or right in the concrete situation (Küng 1998:73). An obligation of conscience, which combines a universal norm as a constant with specific variables determined by various situations, is the need for restitution following the unethical ethical burden of the past. As to the question whether this is achievable, the answer should be an unequivocal 'Yes!'

Over the last decade, the Parliament of the World's Religions has proved that various religions could cooperate through interreligious and spiritual communities in the pursuit of creative solutions to the world's most pressing problems. It also includes the finding of common values and principles for promoting a value of solidarity and a just economic order (see Parliament of the World's Religions 1999). The framework of principles, as articulated by the Parliament, could serve as a point of departure.

This undoubtedly can also be achieved in the South African context. Do we have to remind ourselves of the invaluable role that the clerics such as Beyers Naude, Johan Heyns, Allan Boesak, Frank Chikane and many others have played in the Apartheid era in bringing the various interest groups to a point of real dialogue? This ought to happen again in order to reshape and direct the present unattainable and conflict infested discourse of the present moment. This might be the last chance to renew ethics and economic growth.

\section{Theoconomy: An ethical paradigm for discernible growth}

As mentioned before, a recent doctoral study under the auspices of the Unit for Reformational Theology and the Development of the South African Society has formulate the broad outlines of a shared ethics for a new economic model labelled 'Theoconomy', the tenet which are founded upon the shared ethics as contextualised by the Parliament of the World's Religions and the ethics of Adam Smith, the father of modern economics.

The essential foundation of theoconomy as a new economic model for discernible growth (see Walters 2018:336-359) are deeply rooted in the Golden Rule of Humanity as a categorical imperative and articulated by various religions as a shared ethic and also incorporated in the National Development Plan of South Africa. The study, under the pretext of 'Theoconomy', expound various shared ethical principles and rules that, if entrenched in the socio-economic arena, could fundamentally address the trust and the ethical deficit that prevails in South Africa Incorporate and place the South African economy on a growth trajectory that is discerning in nature, scope and influence.

The shared ethical principles and rules, as formulated in the study, could provide a useful framework from which to commence formulating a shared ethos and shared ethics for the economic household. The study examines the shared theocratic ethical principles in terms of eight principles or standards by which ethical and moral views and principles may be judged or decided upon. These shared ethical principles and rules were found to be rather deontological than teleological in nature and content. It could therefore form the foundation from which an ethics for the economic household could be formulated which are reliant upon fixed principles rather than being consequential or utilitarian in nature and scope. The study further identified eight posteriori criteria as deduced from the unfolding new postsecular paradigm and found that the shared theocratic principles and rules are most suitable and responsive to the new conditions of the reality that is unfolding in the postsecular world. Thirdly, the shared theocratic principles and rules are most suitable as a shared ethic for a global society that are characterised by heterogeneity and polycentricism. The theocratic principles and rules, as further examined and expounded in the research study, could therefore be the core tenets of a shared ethics for a new economic order in South Africa.

\section{Conclusion: Discernible growth}

The socio-economic challenges of the South African economy is complex and vast. The socio-economic challenges that South Africa Incorporate faces, are not unique, but indeed a world occurrence. What makes the challenge more ubiquitous in the South African context, is the intensity and deeply entrenched nature and character of the inequalities in society that are founded upon the unique history and heritage, and further compounded by the prevailing trust and ethic deficit as well as the consequential sophisticated and self-inflicted war that prevails. These challenges are of a systemic nature and require no quick-fix solutions, but instead a systemic solution. It is the line of thought in this article that such a systemic solution should include, inter alia, a fundamental change in human attitudes and behaviour especially in the arena of the economic household. It is further argued that a bold initiative is needed to operationalise and institutionalise a new shared vision and shared ethics that resonate the need to build on our social solidarity in order to address the fundamental challenges emanated from the South African unique history and heritage. Such boldness ought not to be feared, but rather embraced by all sensible and reasonable persons. Providing such bold initiative is not founded upon political expediency and consequentialism, but rather shaped and guided by sensible and reasonable people from a larger denomination of 'people of faith', intellectuals, academia and civil society. This will ensure that the outcome will contain the trust and ethical deficit, and provide a framework for the operationalisation and institutionalisation of an economic discourse or growth strategy that is most discernible not only in our individual and societal aspirations, but also in our economic endeavours.

In so doing, South Africa Incorporate will give expression to the universal fact that humanity - all people - are universally blessed and graced with abundance of life and that all of humanity is entitled to the 'greatest possible quantity of 
happiness that is maintained at all times by the unalterable perfections of God - The Author of Nature' (Smith 1759:235). This is then essentially the purpose of theoconomy as a new economic model that aims to advance a discernible growth strategy that are founded on shared and mutually accepted prosperity ethics.

\section{Acknowledgements Competing interests}

The authors declare that they have no financial or personal relationship(s) which may have inappropriately influenced them in writing this article.

\section{Authors' contributions}

J.M.V. contributed to this article by giving experimental inputs, revising the final product as well as contributing to the writing and final editing of the article.

\section{References}

Abedian, I., Mosala, I. \& Sehume, J. (eds.), 2018, Seeking the ethical foundations of the South African nation, Mapungubwe Institute for Strategic Reflection (MISTRA), Johannesburg, Gauteng, South Africa.

bbc.co.uk., 2018, Retrieved from ethics: A general introduction, viewed 09 July 2018 from http://www.bbc.co.uk

De Klerk-Luttig, J., 2018, 'Tyd dat almal hul plig besef', Rapport Weekliks, 15 April, p. 7.

De Lange, R., 2017, 'Oor die ore in die skuld - Suid Afrikaners verdrink in die skuld', Rapport Sake, 14 Mei, p. 2.

Department of Trade and Industry, 2018, 'Towards full-scale industrialisation and inclusive growth, 10 reasons why we should invest in South Africa', Saturday Star, 28 July, p. 9.

Du Preez, M., 2018, Radical economic transformation of State only way to eradicate inequality, viewed 06 June 2018, from https://m.news24.com
Godongwana, E., 2018, 'Wekroep tot aksie', onderhoud op Netnuus, 05 September.

Ka'Nkosi, S., 2016, 'Minimum wage is only small in the right direction. The shake-up', Business Report, 30 November, p. 18.

Küng, H., 1998, A global ethic for global politics and economics, Oxford University Press, New York.

Liebig, J.E., 1994, Merchants of vision, Berret-Koehler Publishers, San Francisco, CA.

Naidoo, J., 2017, 'Interview with G, van der Westhuizen for the Beeld', Organising Tomorrow, Today, 17 March, p. 13.

National Planning Commission, 2011, National development plan, Government Printers, Cape Town.

Packirisamy, S., 2018, South African politics and the economy: Where do we stand andwhere are we headed, viewed 18 August 2018, from http:/www.businesslive. co.za

Parliament of the World's Religions, 1999, A call to our guiding institutions, Council for a Parliament of the World's Religions, Chicago, Illinois.

Rajab, D., 2016, 'Empower people to conquer poverty', Pretoria News, 06 December, p. 6. Robinson, F., 2018, 'Die regte kultuur begin hier', Beeld 17 May, p. 19.

Roux, A., 2017, Opinion economic growth in SA: What has gone wrong, viewed 23 October 2017, from https://www.businesslive.co.za

Schüssler, M., 2017, 'Ekonomiese herstel: Suid Afrika kan weer groei', Sake Beeld, 16 Augustus, p. 14

Schüssler, M., n.d., Om die werkloosheidsyfer tot $5,5 \%$ te verlaag soos die Nasionale Ontwikkelingsplan beoog-kan tot 22 jaar neem, besigtig 03 September 2018, vanaf https://www.netnuus.com/

Smith, A., 1759, The theory of moral sentiments, Edinburgh, London. (Printed for A. Millar, in the Strand; and A. Kincaid and J. Bell).

South Africa - Economic forecast, 2018, viewed 29 August 2018, from https:// tradingeconomics.com/south-africa/indicators

Stadler, H. \& Prince, L., 2016, 'SA val nie op rommelhoop: Nou moet land eerlik wees', Beeld, 03 Desember, p. 4.

Terreblanche, S.J., 2012, Lost in transformation, KMM Review Publishing Company (Pty) Ltd, Sandton.

The World Bank, 2018, South Africa economic update jobs and inequality, The International Bank for Reconstruction and Development, Washington DC.

Van Zyl, G., 2017, Opinion, viewed 17 July 2017, from http://www.biznews.com

Vorster, J.M., 2007, Christian attitude in the South African liberal democracy, 1st edn., Potchefstroom Theological Publications, Potchefstroom.

Walters, J., 2018, 'Theoconomy: An ethical paradigm for discernible economic growth - A global ethical perspective', PhD dissertation, North-West University, Potchefstroom. 